\title{
The Role of Civic Education in the Student Moral Development in Elementary School: A Descriptive Study
}

\author{
Lisnawati Rusmin*, Sakka Hasan, La Rabani, Mansyur M, I Ketut Suardika \\ Elementary School Study Program, Halu Oleo University, Kendari City, 93231, Southeast Sulawesi, Indonesia
}

Received July 14, 2020; Revised October 19, 2020; Accepted October 24, 2020

\section{Cite This Paper in the following Citation Styles}

(a): [1] Lisnawati Rusmin, Sakka Hasan, La Rabani, Mansyur M, I Ketut Suardika , "The Role of Civic Education in the Student Moral Development in Elementary School: A Descriptive Study," Universal Journal of Educational Research, Vol. 8, No. 12, pp. 6405-6414, 2020. DOI: 10.13189/ujer.2020.081206.

(b): Lisnawati Rusmin, Sakka Hasan, La Rabani, Mansyur M, I Ketut Suardika (2020). The Role of Civic Education in the Student Moral Development in Elementary School: A Descriptive Study. Universal Journal of Educational Research, 8(12), 6405-6414. DOI: 10.13189/ujer.2020.081206.

Copyright $\odot 2020$ by authors, all rights reserved. Authors agree that this article remains permanently open access under the terms of the Creative Commons Attribution License 4.0 International License

\begin{abstract}
Moral education is necessary from an early age for instilling in students. Nonetheless, moral education cannot be distinguished from the instruction of conduct and etiquette by a teacher, but also how values can be applying in social life. Implementation in social studies is closely related to how to live, especially cultivating children in the school environment. The purpose of this study is to investigate the role of moral education in elementary schools. This study uses a descriptive qualitative approach with the triangulation method. The subject of research is at one of the schools in elementary school 14 Kendari Barat. The finding of this study is that respect and responsibility are two fundamental moral values that must be taught to students in school. Furthermore, Moral values are given to students in elementary school 14 Kendari Barat is honesty, responsibility, discipline, caring, cooperation and democracy. All these values a positive influence on the child's behavior if appropriately taught. It takes a good collaboration of the school and the family in the process of development of moral values to children.
\end{abstract}

Keywords Moral Development, Civic Education, Behavior, Education

\section{Introduction}

Nowadays, education process, and continually evolving towards better to produce the generation of graduates expected by the community [1], [2]. The Indonesian people continue to strive to conduct quality education by the demands and the times in this era of technological and communication [3], [4]. Repair for improvements aimed at producing talented human resources, skilled, independent and morality through education [5], [6]. To create such superior graduates, providing education also always evaluated and improved. These far, providing instructions rated yet fully succeeded establish Indonesian people with character [7], [8]. This assessment is based on a variety of behaviors conducted by students and school graduates who do not fit into the noble goals of education [9]. For example, cases of corruption that turns performed by state officials which are a well-educated. Furthermore, the behavior of some Indonesian is teenagers who do not reflect themselves as educated teenagers [10]. For example, involved brawls between students, drug cases or even committed immoral act [11].

Wiyani [12], reported some immoral behavior or delinquency did by elementary school students, including (1) Delinquency of students committed intentionally or unintentionally which is still in the stage of misdemeanors, namely: throw garbage on the street through the window, defied or disobeyed the rules, often surprising female students, mock with harsh words, play cheat, make noise when lessons. (2) Delinquency of students committed intentionally included in the level of gross violation, namely: prevaricate, asking for money to forcibly juniors, cheat on an exam.

Various behavioral deviations committed by students or students indicate that the lack of understanding or awareness of them will be moral [13], [14]. During the 
implementation of education in both primary and secondary school levels more emphasis put on the cognitive aspects of affective and psychomotor aspects [15]. It causes inequality in the world of education. Education shapes intelligent students but their skills, independence and morals are questioned [16], [17]. Ideally, education does not only equip students with various knowledge and thinking skills but also moral awareness which is very important for life [18], [19]. This moral cultivation should begin early in elementary school [20], [21]. It has been a long time; the school realized the importance of moral civic for their students, although the implementation has not been able to run optimally. Through good habituation behavior, the school seeks to form students' awareness of moral.

Of course, seeing this situation, Civic Education is one of the subjects where the teaching of moral values can play an active role in awakening and shaping the character of students, thus becoming a good citizen and intelligent [22]. Civic education is one of the subjects that must be included in the curriculum of primary and secondary education as stated in Article 37 paragraph (1) of Law Number 20 of 2003 on National Education System which states that "Civic education intended to shape students to be human beings who have a sense of nationalism and love for the homeland" [23], [24]). This context that the actual basic education lessons are not only oriented on providing knowledge alone but also seeks to provide planting moral values [25]. The Civic Education subject must contain material that is expected to make students have more values and high morals [26]. Therefore, teaching and learning activity is very dependent on the ability of teachers to deliver and organize learning materials and class management [27]. The success of the learning process in the classroom is essentially a learning success of students supported by the teachers' success [28].

A good education is an education that not only produces students who have intelligence but also have moral intelligence [29]. Moral intelligence is how students can distinguish between good and bad [30]. It is because what students do is not necessarily good even though it is true. Sometimes students feel what he does is correct, even though he does is contrary to the moral force in the school environment. Therefore, students need good role models during the learning process [31], so they get a picture of what is called good and evil. The development of moral intelligence held in the school environment should involve all academic staff, such as teachers and employees. It is because; the teacher has a vital role in developing the terms of affective students in addition to parents and the community a place to stay. Teachers do not only act as educators and instructors but also as role models for students [32].

Students are said to be moral if they have moral awareness; that is, they can judge good and bad things. Things that can be done and things that are ethical and unethical; Students who are immoral in itself will appear in the assessment of moral reasoning and behavior on a good, faithful, and ethically. That is, there is unity between moral reasoning with moral behaviour [33]

Based on the pre-study conducted by researchers at the elementary school 14 Kendari Barat; This school located in Merpati street, Kendari City has sought to establish her students personally as expected by the community, nation and religion. Head of school (elementary school 14 Kendari Barat) said that the students had behaved well. However, the attitude of respect for parents was still lacking. Following the vision and mission of the school, elementary school 14 Kendari Barat to implement good habits for its students since the early morning before learning takes place until the day when students get home from school. Every morning when students come to school, they always greet and kiss the hands of teachers. Every day before classes begin, class teachers always take the time to give honest advice to their students. When it comes to midday prayer students are accustomed to praying in congregation. Moreover, there is another thing that researchers found in this school that students consciously handed over the money they found in the school area to the administrative staff. It indicates that the value of honesty already ingrained in the students' (Discussion with the principal).

Apart from being excelled in academics, Elementary School 14 Kendari Barat students also have good behaviour. The behaviour of students shows it. At the same time, in school, the teachers appreciated, admonish greet fellow students, running a school discipline. The 2013 curriculum, which is used as a guideline by this school in realizing educational goals, also demands teachers to be able to improve the effective and psychomotor sides of students in addition to cognitive abilities. It is due to vote on the 2013 curriculum include assessment of cognitive, affective, and psychomotor. There are some teachers in schools, and teachers of Civic education is one teacher who is responsible for developing the right side besides homeroom students and teachers of religious education. Then how do teachers of Pancasila and Civic Education teach about morals and develop students' moral intelligence in the swift currents of globalization?.

In the learning process, civic education teachers in elementary schools are required not only to teach but also how to instill students' moral behavior, especially in the current era of globalization. Teachers do not only design simple lessons (starting from perceptions, teaching strategies, and closings, but also teachers can create a learning environment and an active learning process, inspire, motivate, and foster multiculturalism, and instil moral values in the context of everyday life so that later students are expected to be children who can accept and respect other people from tribes and different cultures [34].

Implementation of civic education learning in elementary school, especially in elementary school 14 
Kendari Barat has sought to instill moral for students. School principals are well aware that to instill morals in school, needed a good example of teachers. Therefore some principles must be upheld by the teachers in this school, namely religious, honest, disciplined, responsive, and friendly responsibility. The school principal said that the students in the school have a close relationship with the teachers but still have respect. It is because students respect the character and role models of teachers. Based on the Pre-study and interview, the researcher is interested in finding out more about the implementation and what programs are implemented in elementary school 14 Kendari Barat in moral cultivation for their students. Therefore, researchers are interested in conducting studies on the topic the role of civic education in the moral development of students in elementary school 14 Kendari Barat. The objective of this study was to determine the role of moral education students in elementary school 14 Kendari Barat. This study would be expected to provide an overview of the implementation and inclusion of moral cultivation in schools as a science treasure.

\subsection{Problem of Study}

The problems that will be studied in this research are:

1. How moral development through self-development program on students in elementary school 14 Kendari Barat?

2. How moral development of students through the integration of morals in civics subjects in elementary school 14 Kendari Barat?

3. How moral cultivation through the development of school culture in elementary school 14 Kendari Barat

\section{Methods}

This study was included in descriptive research. Researchers intend to describe in a systematic and profound moral development student in elementary school 14 Kendari Barat using a qualitative approach. This research was conducted at elementary school 14 Kendari Barat, located in Merpati Street Benu-Benua Kendari City. Subjects in this study were principals, teachers of class I, II, and VI elementary school 14 Kendari Barat. Determination of Subjects in this study based on the consideration that they are the parties most familiar with the situation and conditions related to what investigators wanted to know. It is because the parties directly involved in the implementation of moral development in elementary school 14 Kendari Barat. The selection of subjects with specific considerations and objectives is with the purposive technique.

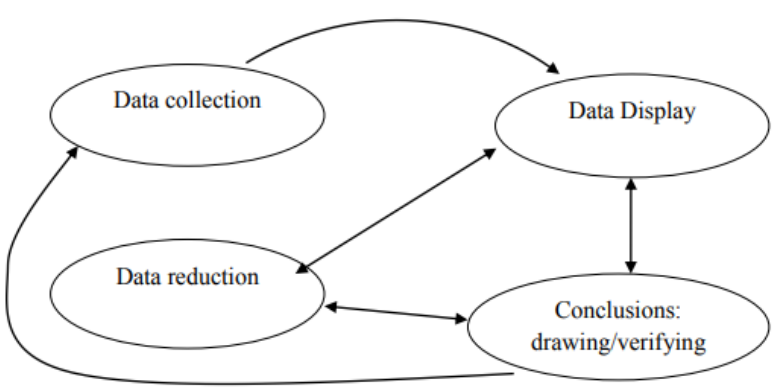

Figure 1. A component in date analysis (interactive model)

Figure $1 \mathrm{a}$ form of strategy, which is a special kind of pattern matching. However, the procedure is more complicated and therefore deserves particular attention. Here, the goal to analyze the qualitative data to construct an explanation of the situation. To "explain" a phenomenon means establishing a set of causal relationship about it. Improving the accuracy of pattern matching described Figure 1, and the analysis of the development of the explanation is one of the key strategies in the search for the typical behavior and the practical limits of a quantitative indicator [35].

In this study, Data collection techniques used include observation, interview and documentation. Data analysis techniques such as planning steps, start the data collection, primary data collection, data collection and complimentary cover. In this study, the data analysis techniques used are interactive models of Miles and Huberman [36]. Miles \& Huberman [36] explained that there are three types of activities in data analysis, namely data reduction, data display, and conclusion drawing/verification. The credibility test in this study was carried out through triangulation, an extension of observation and member check.

The credibility test in this study was carried out through triangulation, the extension of observations and member checks. The triangulation used is technical-triangulation techniques done by checking the data to the same source with different techniques-for example, the data obtained through interviews, then checked by observation and documentation. If the data obtained through such techniques vary, the researchers conducted further discussions with the relevant data source or another, to ascertain which data are assumed to be true. In addition, the triangulation techniques, the researchers conducted a test of credibility with triangulation that is checking the data that has been obtained through several sources. Data have been obtained and analyzed further requested the agreement (member check) with multiple sources of data. Member check intended that the information obtained by what is meant by data providers[37]. 


\section{Result of Investigations}

\subsection{Description of School}

Elementary school 14 Kendari Barat have a yard large enough. On the edge of the yard planted with shade trees. In the middle of the page, there is a soccer field. To the north of the area, there are places like a pavilion equipped with a television and sound system. In the west, there is a school cafeteria clean and comfortable. Some flowerpots are placed in front of the class. In the north cafeteria, there is a school library adjoining room School Health Unit. Garbage bins neatly arranged in front of each classroom. The school building still looks like a new sturdy and robust construction with adequate lighting and proper ventilation. The overall physical condition of school buildings is always good

\subsection{Vision, Mission, and Objectives Elementary School 14 Kendari Barat}

Elementary school 14 Kendari Barat has the following vision: "Being a school that can form people faith, devoted, intelligent, skilled, independent and have a noble character". Elementary school 14 Kendari Barat has the following mission:

1. Instilling the values of faith and piety continuously through imtaq and early habituation.

2. Develop active learning, innovative, creative, effective, and fun.

3. Improve the competence of students in various competitions from school level to national level

4. Improve discipline school community (teachers, staff and students

5. Intensively cultivate the spirit of excellence in the entire school community.

6. Implement extracurricular activities that foster discipline and noble character

7. Improving the implementation of security, order, cleanliness, beauty, kinship, shade and comfort Implementing and participatory, transparent and accountable

The objective of elementary school 14 Kendari Barat specifically:

1. Improve the role and functioning of schools as an educational environment to produce graduates with the range and level of knowledge, the ability, skills, and values and attitudes that enable it to become citizens and citizens who are virtuous, have good faith and have faith in God Almighty, and have the ability and necessary skills that can become provisions to continue their education and to live in a society.

2. Develop existing resources in the school and its environment and utilize effectively and efficiently in improving the quality of education in primary schools.
3. Improving the ability of professional staff, in planning organizing, directing, motivating the implementation, coordination, evaluation and educational innovation towards the achievement of primary school education.

4. To make personal students aware of their safety, families, schools and the community.

Elementary school 14 Kendari Barat has the following vision: "Being a school that can form people faith, devoted, intelligent.

\subsection{Description of Role Learning Research of Civic Education in Elementary School to the Moral Development of Students Elementary School 14 Kendari Barat}

\subsubsection{Personal Development Program}

\section{a. School Routine Activities}

Researchers collected data using interview, and observation techniques based on the results of interviews and observations obtained data about the implementation of moral cultivation in elementary school 14 Kendari Barat the review of aspects of self-development programs, integration of subjects, school culture, and the development of the learning process. Description of the following results:

Interviews with principals and teachers showed that the shape of regular activities undertaken within the framework of school students' moral cultivation is about Moral Teaching through Civic learning and religion, Morning Prayer; discipline came on time, and checks the activity book. Results of interviews with principals and teachers, reinforced by the results of the implementation documentation Tadarus activities and Morning Prayer. Sometimes the teacher has not entered class because of the meeting; students automatically start the Morning Prayer. Consecutively there is a student who led a prayer-students arrived late stand in front of the class and pray alone in front of the class. To train student discipline, teachers usually give educational sanction-penalties such as being asked to take out the trash.

Results of interviews with principals and teachers to check the teacher's activities related student activity book strengthened by the observation of which have researchers did; Every day the teacher checking the student activity book for the home. In the activity book, students are asking to get a parent's signature related to student learning and worship activities at home. Then bring the book back to school the next day. This activity book intended as a means of communication between parents and teachers in monitoring student development. The results of interviews and observations related to student activity books. 


\section{b. Spontaneous Activity}

Researchers put the question to the school principal about what is done principals and teachers spontaneously when students misbehave decently well against their peers, teachers, employees or principals. The results of the interview as follows:

School principal: Trying to find the data, incivility of any. If the data is valid, I usually bring witnesses who saw. After that, I called to my room. I asked later I advised." (Wednesday, November $1^{\text {st }}$, 2017)”.

Based on interviews with principals indicate that random thing was done by the principal when students behave in a less courteous towards fellow, teachers, employees or school principals are looking for forms of impoliteness, being questioned and then advised. The principal school statement supported by a speech delivered by the teacher as follows:

Teacher: Immediately sanctioned, we call, we advise, we ask the reason what, what purpose, like that. If you already know, what is the reason we tell that it is wrong and do not repeat it? We advise, given examples of the consequences."

\section{c. Exemplary}

Based on the results of the study, showed that the example given by the principal and teachers to students includes the principal and teachers always wear clean clothes, and polite following applicable regulations, an example in discipline, still maintaining cleanliness, a case in terms of morality and manners. In the implementation of moral cultivation of students, exemplary principals and teachers have an essential role. According to Fathurrahman [38], the teacher should present himself as a sympathetic, authoritative figure in maintaining karmic discipline and always pleasant.

Principals and teachers as educators must always give an example and become role models for students. It is by the Pusat Kurikulum dan Perbukuan [39] that exemplary behavior and attitude is the principal, teachers, staff, and students in providing a good example, through the actions that can be role models for other learners. The principal always arrives on time even earlier than the expected arrival time. The first arrival time is 06:30 a.m. Teachers always try to come to school on time, which is at 6:45 a.m. Every day the teachers, employees and principals always wear clothes that are clean, neat and polite according to applicable regulations. School principals, teachers and employees always try to maintain cleanliness in the classroom and office. After finishing work, I always tidy up the desk and leave the office clean. The teacher realizes that every word is still seen and imitated by students. Therefore the teachers always keep their names and speak well and politely, especially when there are students around.

\section{d. Conditioning}

The conditioning done by schools in implementing students' moral cultivation is reflecting on the results of the research description. Based on the results of the study, the conditioning conducted by the school is to create a comfortable learning atmosphere, the existence of school rules, and picket schedules. The conditioning carried out by this school is under the opinion of Narwanti [40] that conditioning is a school effort to create a physical and non-physical environment that supports the implementation of character education.

The school strives to create a comfortable learning atmosphere for students. Physical conditioning carried out by the school is to plant shade trees in the yard. The purpose of planting these trees is to create a comfortable learning atmosphere at school. The school displays the vision, mission and goals of the school as well as school order in a strategic place. Besides, the rules and schedule of pickets are installed in each class. The purpose of establishing the code of conduct is so that all school residents are aware of the laws that apply in the school and comply with them. Installation of picket schedules in class aims to train students to have a sense of responsibility within them. In addition to physical conditioning, there is also non-physical conditioning by the teacher in the classroom. Non-physical conditioning is carried out among others by preparing children to be ready to receive lessons and giving moral messages to students.

\section{e. Integrating moral in Subjects}

Based on the results of the study, the integration of moral cultivation in subjects is done by teachers by integrating moral values related to all topics. We are incorporating moral values in learning materials, especially in the learning process. The teacher also includes the amounts to be achieved in the learning process in the learning implementation plan. The teacher always provides reliable advice and appeals to students useful information related to the subject matter includes: speaking well and politely, respecting others, respecting other people's belongings, and being honest. It opinion of Wiyani [12], learning activities in addition to making students master the competencies targeted, also designed and carried out to make students know, care and internalize values and make its behavior.

Moral values are implemented and conveyed in integration in subjects. It shows the relationship between Competency Standards and Basic Competence with values and indicators to determine the developed moral values. Include costs related to morals in the implementation of learning plans.

In its implementation, the teacher has tried to link the subject matter with moral cultivation in students. In social studies lessons in class III, when bartering, the teacher reminded students to speak politely and not mock friends' stuff. The value that appears on barter material is to respect the property of others. In civic lessons in class $\mathrm{V}$, the teacher asks students to practice deliberation. The teacher reminds students how to do good and right considerations, the teacher, also encourages students to respect friends who 
speak in front. The value that appears in the material discussion is speaking politely and respectful of others. In mathematics, the teacher asks students to be confident in doing the assignments and not see the answers of peers. Values that appear in mathematics are confidence and honesty. In Indonesian Language lessons in class II, students practice the drama dialogue they have made. The teacher gives direction on how to read drama discussion well. The teacher also asks students to pay attention to their friends who are practicing the drama dialogue in front. Values that appear in drama material are paying attention to lessons and respect for others.

\section{f. School Culture Development}

Based on the research results, the school culture developed is related to the implementation of moral cultivation in elementary school 14 Kendari Barat, including by arranging programs related to moral cultivation. The programs that are cultivating included in the school order, security, order, cleanliness, beauty, family, hospitality, and comfort programs. While the policy made by the teacher/father related to moral cultivation in the classroom is to create an agreement together with students and always advise or remind students. The programs and policies at elementary school 14 Kendari Barat are under the Kementerian Pendidikan Nasional Indonesia [41] that school culture is an atmosphere of school life where students interact with their fellow students, principals, teachers, and other school residents.

Schools have the principle of using a humanistic approach in every school activity. Rules are made by schools to support the achievement of the school's vision and mission. In addition to the rules, there are also sanctions for those who violate them. Schools impose sanctions that are educational, for example, by taking out the trash.

\subsubsection{Development of Learning Process}

\section{a. Class}

The results of the study concluded that the development of the classroom learning process carried out was by reminding students, giving moral messages, giving assignments and making mutual agreements with students. Efforts to develop classroom-learning processes carried out by the Kementerian Pendidikan Nasional Indonesia [41] that which states that the class, through the learning process of each subject or project that designed in such a way. The efforts of the teacher in the classroom through collective agreements aimed at training democratic students to express their opinions. This cooperative agreement encourages students to take responsibility for accepting and fulfilling what has been agreed between the teacher and students. In addition to the contract with the teacher inserts and provides moral messages to students the learning process in class. The teacher also always reminds students if they behave or behave disrespectfully while in class. The assignment of tasks intended to train students to have a sense of responsibility within them.

\section{b. School}

The development of the school learning process carried out by elementary school 14 Kendari Barat is to hold guidance and counseling both through the school and from outside the school. The school conducts recitation activities and meetings with parents. It is by the Kementerian Pendidikan Nasional Indonesia [41] that which states that schools, through various school activities participated by all school members, were designed by the school since the beginning of the school year, and included in the Academic Calendar and carried out daily as part of the culture school. Meetings with student guardians held by the school are aimed at the socialization of school programs and providing input from parents to the school. Guidance with student guardians is held once a month in the second week, with material related to ways to educate children. Besides, the study also aims to foster cooperation with parents. Every once a year, the school also conducts counseling for grade VI students related to the dangers of drugs in collaboration with the police.

\section{c. Outside the School}

The development of an out-of-school learning process carried out in elementary school 14 Kendari Barat in the implementation of moral cultivation is by adding hours of activity or extracurricular activities. Extracurricular activities at elementary school 14 Kendari Barat include $H W$, Scouts, and TPA. The procurement of extracurricular activities in elementary school 14 Kendari Barat is by the opinion of Wiyani [12] states that extracurricular activities are activities carried out in developing specific aspects of what is found in the curriculum being implemented, including those related with how the actual application of science learned by students under the demands of their lives and the surrounding environment.

All extracurricular activities in elementary school 14 Kendari Barat can be linked to the implementation of moral cultivation. The school held a camping trip every year, with students in 4th and 5th grades. This camp activity is part of the physical training of students. This camp aims at teaching students to become more responsible for themselves, their families, their academics and their communities.

\subsection{Civic Education as a Moral Education}

The new paradigm of Civic Education has changed in several aspects; vision, mission, material substance, teaching strategy, and performance [42]. In the old paradigm, Civic Education manifests as those of the powerful indoctrination da moral standards monologues.

Awareness of moral values directs children to be able to make careful considerations of their behavior in everyday 
life both at school and in society. Because moral awareness in education is still significantly less attention, a lot of cases or issues related to the moral consciousness of particular concern in the world of education. Moral makes a healthy person in society even in education for sustainability education of generations achieve a decisive moral and academic appropriate educational goal.

Moral issues are problems that are currently asking much attention, especially from educators, religious scholars, community leaders and parents. We endlessly listen to the complaints of parents who are confused about their children who are difficult to obey, stubborn and naughty. Many teachers are confused about their students, who cannot receive education and do not want to study. Nevertheless, I want to go to class, want to pass the exam and want to impose their will on the teacher. Newspapers always carry worrying news, about the symptoms of moral decline, which are multiplying in recent times. There have been many attempts to overcome this moral decline, both by religious, educational and social institutions; and government agencies[43].

Moral education is one of the epistemological components of Civic Education. Daniel Dakhidae [44] emphasizing that one of the roles of Civic Education (civic education) is to provide guidelines for the cultivation of

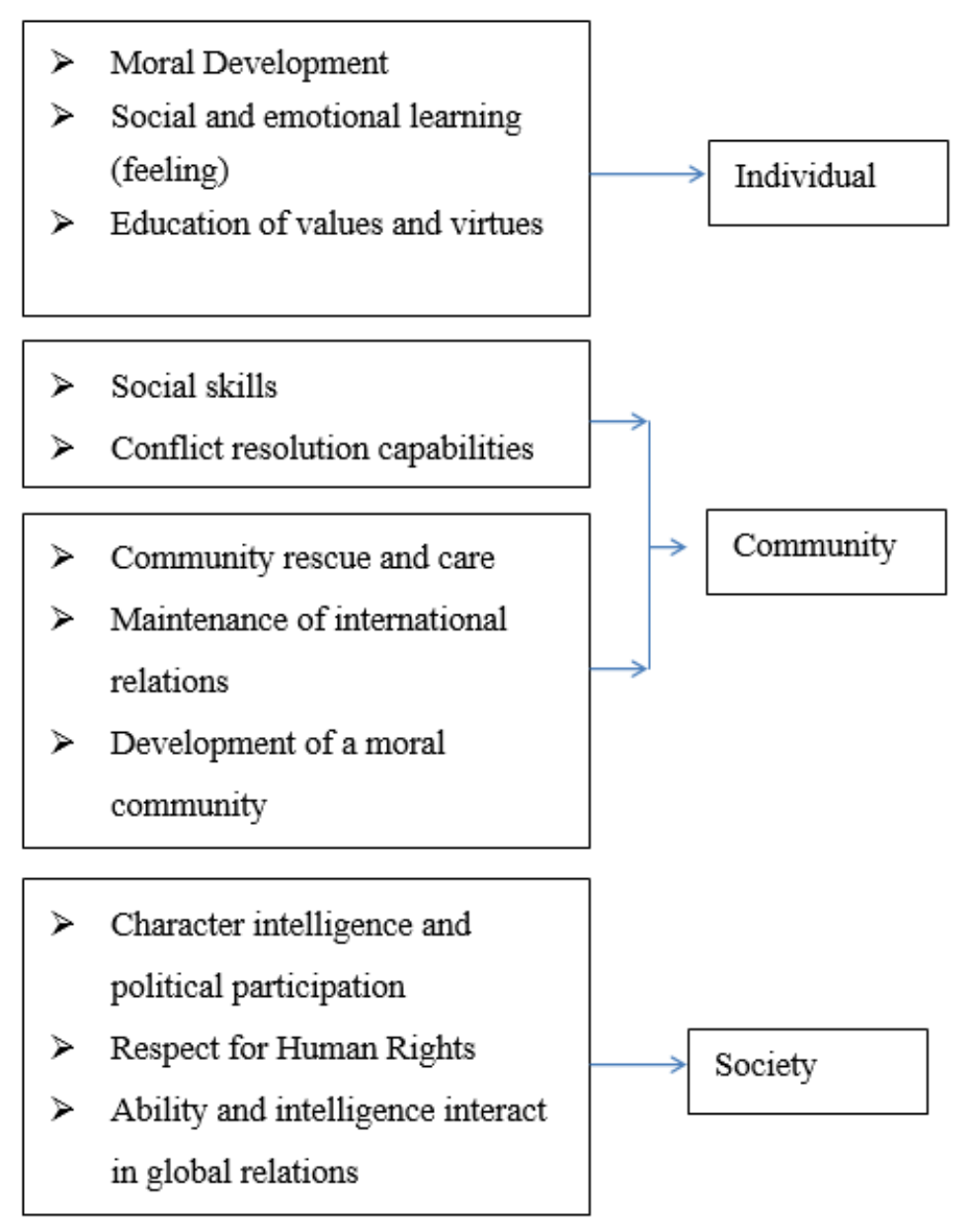

ideological values that are considered high by a nation for its future generations, making humans homo novi-ordinis, namely humans who have reached the perfection of life, have great souls and are truly good. With this paradigm, Civic Education can take a role in the framework of the construction, reconstruction, and the resolution of issues that arise in various sectors of life of the Indonesian people, through learning the civic knowledge, the civic values, and the civic skills. One of the dominant values studied together in Civic Education is ethics or morals. On this side, the teaching of ethics in Civic Education includes three categories at once, the descriptive ethics, normative ethics and meta-ethics. The third category is the subject of teaching ethics Civic Education as a moral or character education.

In character (moral) education, it is essential to develop core ethical values such as caring, honesty, fairness, responsibility and respect for oneself and others, along with the values of supporting performance such as persistence, high work ethic, and persistence. As a good character base; These core values aspects are the coverage of affection aspects which must be the main content in every Citizenship learning [45].

Moral education has a gradual relationship with Civic Education, as shown in Figure 2.

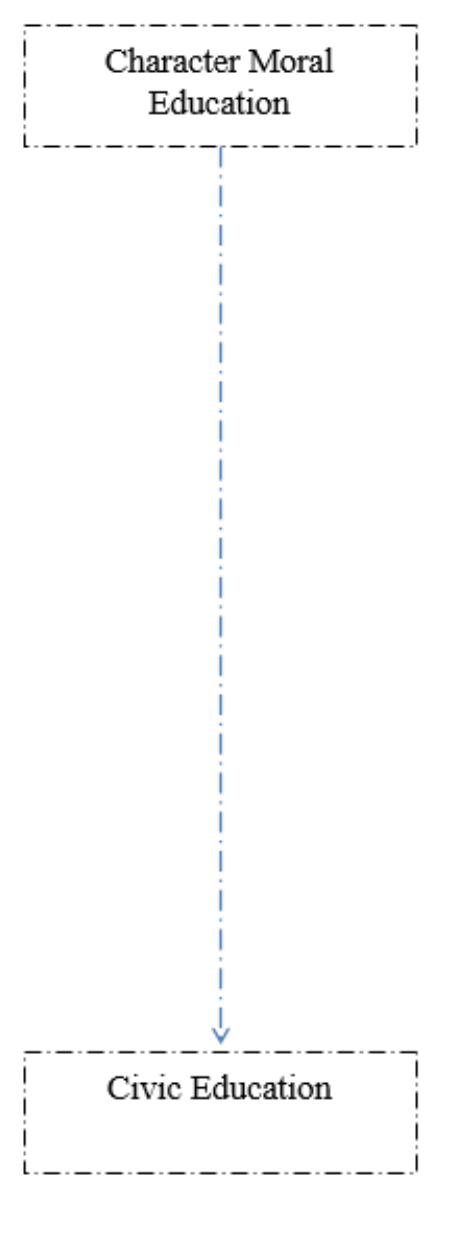

Figure 2. The Relationship between Gradual Moral Education and Civic Education 
Discussing the issue of Civic Education in such a perspective, we are reminded of the dynamics of Civic Education in its phase as moral education, which in the formal curriculum is called Pancasila Moral Education. Must explicitly say that Civic Education in the development phase is substantive is not moral education. Therefore, learning in it only fed private moralities to the students. At the same time, they have turned away from the problems of public ethics [47].

Therefore, the role of civic education in supporting moral education is crucial in order to form student character and culture. The role of education can cultivate students' skills in terms of logical thinking especially forming patterns and patterns of discipline in students appreciate both between students and students, students and teachers as well as students in the environment. With the existence of moral education in students, it becomes a perspective in supporting student activities in building identity and morals in everyday life. So that with the application of moral education in Elementary School 14 Kendari Barat, it hoped that it would become a forum and an example for other schools informing students to have good character, discipline and not forgetting to leave worship to the Almighty.

\section{Conclusions}

Based on the results of the investigation, it was founded that the implementation of moral cultivation in elementary school 14 Kendari Barat through (1) Personal development program. Personal development programs include routine activities, spontaneous activities, exemplary principals and teachers, and conditioning in supporting the implementation of moral cultivation. (2) Integration in subjects. Teachers do combination in subjects by linking moral cultivation with the subject matter. (3) Development of school culture. The development of school culture is carried out by arranging programs related to ethical agriculture, such as making rules, the $10 \mathrm{~K}$ program. (4) Construction of the learning process, including the development of classroom, school and non-school learning processes. Classroom learning by giving moral messages, reminding students and mutual agreement; Schools by providing guidance or counseling both through the school and from outside the school, recitation holding and meetings with guardians of students Outside the school with extracurricular activities such as football, camping, School health programs, Science Study, Drum band, and holding camps for class IV and V students every year.

\section{Acknowledgments}

The author would like to thank for the research grant given by Halu Oleo University and the principal of Elementary School 14 Kendari Barat for support during the research process.

\section{REFERENCES}

[1] K. Lowden, Intelligenc in the flesh, no. October. London: Edge Foundation, 2009.

[2] D. G. Oblinger and james L. Oblinger, Educating the next generation, vol. 48, no. 2. 2008.

[3] M. Iswari, "The challenge of improving special education quality in digital era," J. ICSAR, vol. 3, no. 1, pp. 91-94, 2019, DOI: 10.17977/um005 v3i12019p091.

[4] T. Suratno, "The education system in Indonesia at a time of significant changes,” Open Ed. Jurnals, no. June, 2014.

[5] R. Weissbourd, "Moral teachers, moral students," Creat. Caring Sch., vol. 60, no. 6, pp. 6-11, 2003.

[6] T. Asif, O. Guangming, M. A. Haider, J. Colomer, S. Kayani, and N. ul Amin, "Moral education for sustainable development: Comparison of university teachers' perceptions in China and Pakistan,” Sustain., vol. 12, no. 7, pp. 1-20, 2020, doi: 10.3390/su12073014.

[7] B. Maunah, "Implementasi Pendidikan karakter dalam pembentukan kepribadian holistik siswa [implementation of character education students in holistic personality formation],” J. Pendidik. Karakter, vol. 1, no. 1, pp. 90-101, 2016, doi: 10.21831/jpk.v0i1.8615.

[8] S. Purnomo, "Pendidikan karakter di Indonesia: antara asa dan realita [Character education in Indonesia: between asa and reality]," J. Kependidikan, vol. II, no. 2, pp. 66-84, 2014.

[9] S. Siswati, C. B. Utomo, and A. Muntholib, "Implementasi pendidikan karakter dalam membentuk sikap dan perilaku sosial peserta didik melalui pembelajaran sejarah di SMA PGRI 1 Pati tahun pelajaran 2017/2018 [Implementation of character education in forming social attitudes and behaviors of student,” Indones. J. Hist. Educ., vol. 6, no. 1, pp. 1-12, 2018

[10] A. S. Hidayat, "Pendidikan kampus sebagai media penanaman nilai-nilai antikorupsi bagi mahasiswa [Campus education as a media for planting anti-corruption values for students],” SALAM J. Sos. dan Budaya Syar-i, vol. 6, no. 1, pp. 43-54, 2019, DOI: 10.15408/sjsbs.v6i1. 10498.

[11] T. Handayani, "Korupsi dan pembangunan pendidikan di Indonesia [Corruption and educational development in Indonesia]," J. Kependud. Indones., vol. IV, no. 2, pp. 15-34, 2009, [Online]. Available: https://journal.uii.ac.id /IUSTUM/article/view/3838.

[12] N. A. Wiyani, Membumikan pendidikan karakter di SD. Yogyakarta: Ar-Ruzz Media, 2013.

[13] S. Fitakila, "Peran orang tua dan guru dalam upaya pengendalian perilaku menyimpang siswa smp islam al-istiqomah Depok [The role of parents and teachers in controlling attitudes of students' deviant behavior in midle school islam al-istiqomah Depok]," Sosietas, vol. 7, no. 1, pp. 359-365, 2018, DOI: 10.17509/sosietas.v7i 1.10350. 
[14] A. Yuniati, Suyahmo, and Juhadi, "perilaku menyimpang dan tindak kekerasan siswa smp di kota Pekalongan [Deviant behavior and violence in middle school students in Pekalongan City],” J. Educ. Soc. Stud., vol. 6, no. 1, pp. 16, 2014, [Online]. Available: http://journal.unnes.ac.id/sju /index.php/jess.

[15] S. Sukanti, "Penilaian afektif dalam pembelajaran akuntansi [affective assessment in learning accounting]," J. Pendidik. Akunt. Indones., vol. 9, no. 1, pp. 74-82, 2011, DOI: 10.21831/jpai.v9i1.960.

[16] S. D. Laksana, "Urgensi pendidikan karakter bangsa di sekolah [urgency of national character education in schools]," Muaddib, vol. 05, no. 01, pp. 167-184, 2015.

[17] Ariah, "Pembentukan karakter kemandirian siswa melalui implementasi islamic full day school [Character formation through self-reliance students islamic implementation full day school],” Didakt. Tauhidi, vol. 2, no. 2, pp. 121-128, 2015, [Online]. Available: https://ojs.unida.ac.id/jtdik/articl e/download/309/190.

[18] A. Hartoyo, "Pembinaan karakter dalam pembelajaran matematika [Coaching character in mathematics]," Math Didact. J. Pendidik. Mat., vol. 1, no. 1, pp. 8-22, 2015, DOI: 10.33654/math.v1i1.90.

[19] Samrin, "Pendidikan karakter (sebuah pendekatan nilai) [Character education (a value approach)]," J. Al-Ta'dib, vol. 9, no. 1, pp. 120-143, 2016.

[20] Y. Mahendra, "Pendidikan karakter di sekolah [Character education in school]," Semin. Nas. PAGELARAN Pendidik. Dasar Nas., vol. 1, no. 1, pp. 257-266, 2019, DOI: 10.17509/eh. v3i1.2795.

[21] E. Aini, Nurul, rosman, "Penanaman nilai-nilai moral pada siswa di SD negeri Lampeuneurut [Instilling moral values in students in SD Negeri Lampeuneurut)," J. Ilm. Mhs. Prodi PGSD FKIP Unsyiah, vol. 1, no. 1, pp. 68-77, 2016, [Online]. Available: http://jim.unsyiah.ac.id/pgsd/article/ viewFile/431/262.

[22] K. Komalasari and D. Saripudin, "The influence of living values education-based civic education textbook on student's character formation,” Int. J. Instr., vol. 11, no. 1, pp. 395-410, 2018, doi: 10.12973/iji.2018.11127a.

[23] W. Noe, "Peran pembelajaran pendidikan kewarganegaraan (Pkn) dalam membangun karakter siswa,” Pedagogik, vol. 1, no. 1, pp. 1-15, 2004.

[24] E. S. Nurdin, "The policies on civic education in developing national character in Indonesia,” Int. Educ. Stud., vol. 8, no. 8, pp. 199-209, 2015, DOI: 10.5539/ies.v8n8p199.

[25] M. Meiers, Teacher professional learning, teaching practice and student learning outcomes: important issues, no. June. 2007.

[26] B. Sumardjoko and M. Musyiam, "Model of civic education learning based on the local wisdom for model of civic education learning based on the local wisdom," Cakrawala Pendidik., vol. 37, no. 2, pp. 201-211, 2018.

[27] R. Chandra, "Classroom management tools for effective teaching,” Int. J. Educ. Psychol. Res., vol. 4, no. 4, pp. 13-15, 2015.

[28] Amiruddin, "Peranan guru pkn terhadap pembentukan moral siswa di SMP Negeri 10 Palu,” Edu Civ., vol. 1, no. April, pp. 1-5, 2013.

[29] M. Z. Altan, "Moral intelligence for more diverse and democratic world," Eur. J. Educ. Stud., vol. 3, no. 3, pp. 202-219, 2017, DOI: 10.5281/zenodo.290617.

[30] R. H. Clarken, “Moral intelligence in schools,” Annu. Meet. Michigan Acad. Sci. Arts Lett., vol. 1, no. 1, pp. 1-9, 2009.

[31] P. P. Shein and W. Bin Chiou, "Teachers as role models for students’ learning styles,” Soc. Behav. Pers., vol. 39, no. 8, pp. 1097-1104, 2011, doi: 10.2224/sbp.2011.39.8.1097.

[32] W. S. Liana, "Metode Pengembangan kecerdasan moral siswa oleh guru Ppkn tahun pelajaran 2015/2016 di SMAN 1 Slawi Kabupaten Tegal Jawa Tegah 2016,” Universitas Negeri Semarang, 2016.

[33] S. Firmansyah, "Peran guru pendidikan kewarganegaraan dalam mengembangkan nilai moral yang terkandung di dalam materi demokrasi di kelas VIII sekolah menengah pertama negeri 1 Sungai Raya Kepulauan Kabupaten Bengkayang,” J. Pendidik. Kewarganegaraan, vol. 7, no. 1, pp. 82-90, 2017.

[34] R. Rachmadtullah, H. Syofyan, and Rasmitadila, “The role of civic education teachers in implementing multicultural education in elementary school students," Univers. J. Educ. Res., vol. 8, no. 2, pp. 540-546, 2020, DOI: 10.13189/ujer.2020.080225.

[35] D. Amaratunga, D. Baldry, M. Sarshar, and R. Newton, "Quantitative and qualitative research in the built environment: application of 'mixed' research approach," Work Study, vol. 51, no. 1, pp. 17-31, 2002, DOI: 10.1108/00438020210415 488.

[36] A. M. H. Matthew B. Miles, Qualitative data analysis: an expanded sourcebook, Second Edi. USA: SAGE Publications, 1994

[37] Sugiyono, Educational research methods quantitative, qualitative approach and $R \& D$, First Ed. Bandung: Alfabeta, 2014.

[38] P. Fathurrahman, A. Suryana, and Fenny Fatriany, Pengembangan pendidikan karakter [development of character education]. Bandung: PT Refika Aditama, 2013.

[39] P. K. dan Perbukuan, "Pengembangan pendidikan budaya dan karakter bangsa,” Jakarta, 2010.

[40] S. Narwanti, Pendidikan karakter[character education]. Yogyakarta: Familia, 2011.

[41] "Pedoman pelaksanaan pendidikan karakter [guidelines for character education],” Jakarta, 2011.

[42] E. Kazimzade and I. Silova, "New paradigms and old paradoxes in civic education in Azerbaijan,” J. Azerbaijani Stud., vol. 1, no. 1, pp. 3-17, 2003.

[43] R. Purwanti and L. Susila, "Implementasi pendidikan moral terahadap mata pelajaran,” J. Didakt., vol. 10, no. 2, pp. 110, 2016

[44] D. Dhakidae, "Partai politik dalam sistem kepartaian di Indonesia,” Jakarta, 1981.

[45] Mujtahidin, “Analisis integrasi nilai-nilai karakter dalam 
kompetensi dasar mata pelajaran Pkn Kelas IV sekolah dasar,” Widyagogik, vol. 3, no. 1, pp. 43-65, 2015.

[46] A. Education, The heart of the matter: character and citizenship education in Alberta schools. Alberta: Edmonton, 2005.
[47] Suharno, "Pengembangan aspek moral dalam pendidikan kewarganegaraan SD dan SMP: respons atas realitas keprihatinan moral," J. Civ. Media Kaji. Kewarganegaraan, vol. 13, no. 2, pp. 162-171, 2016, DOI: 10.21831/civics.v13i2. 12739. 